Original Article

\title{
MENTAL HEALTH AND QUALITY OF LIFE DURING COVID-19 PANDEMIC IN INDIAN POPULATION
}

\section{BALVIR SINGH TOMAR ${ }^{1}$, PREETI RAJ ${ }^{2 *}$, SUPRIYA SUMAN ${ }^{2}$, PRATIMA SINGH ${ }^{2}$, DEEPAK NATHIYA ${ }^{2}$}

${ }^{1}$ Department of Pediatric Gastroenterology, Institute of Gastroenterology, Hepatology and Transplant, Nims University, ${ }^{2}$ Department of Pharmacy Practice, Institute of Pharmacy, Nims University, Jaipur, Rajasthan, India

Email: rajpreetipp@gmail.com

Received: 09 Aug 2020, Revised and Accepted: 04 Nov 2020

\section{ABSTRACT}

Objective: As there is a dearth of researches targeting the Indian population on this issue, we decided to conduct a survey to assess the psychological impact of COVID-19 on mental health and quality of life of Indians.

Methods: In this Cross-Sectional study, a total of 2245 participants above 16 y of age were included. Mental health variables were assessed via depression, anxiety and stress subscale (DASS-21), Insomnia Severity Index (ISI-7), Patient health questionnaire (PHQ-15), Quality of life (QoL-5) and social media exposure.

Results: The multivariate logistic regression demonstrated female (OR-1.17, 95\% CI: 0.99 to 1.38) had significantly higher depression scores whereas, housewife had higher depression (OR-1.68, 95\% CI: 1.33 to 2.13), anxiety (OR-1.64, 95\% CI: 1.15 to 2.35 ), insomnia (OR-1.32, 95\% CI: 1.14 to 1.53), somatic symptoms (OR-1.76, 95\% CI: 1.21 to 2.57). Front line workers had a higher psychological impact with increased scores of anxieties (OR-1.23, 95\% CI: 0.79 to 1.53), stress (OR-1.82, 95\% CI: 0.76 to 2.55), insomnia (OR-1.65, 95\% CI: 1.31 to 2.09). Lower education level had significantly higher score in depression (OR-1.14, 95\% CI: 0.73 to 1.32), insomnia (OR-2.42, 95\% CI: 2.07 to 2.84), somatic symptoms (OR-2.59, 95\% CI: 1.80 to 3.37). Poor physical health, social media exposure was significantly associated with heightened anxiety score.

Conclusion: There is a need for psychological intervention as the dynamics and severity of COVID-19 is rapidly changing. These findings could guide the public health authorities to target and implement health measures to combat the pandemic.

Keywords: Mental health, Quality of Life, COVID-19, General Population, India

(C) 2020 The Authors. Published by Innovare Academic Sciences Pvt Ltd. This is an open access article under the CC BY license (http://creativecommons.org/licenses/by/4.0/) DOI: http://dx.doi.org/10.22159/ijpps.2020v12i12.39345. Journal homepage: https://innovareacademics.in/journals/index.php/ijpps.

Speedy peer review was done as the subject of the manuscript was related with pandemic.

\section{INTRODUCTION}

For the first time after post-war history disease pandemic is re-writing history. Impacting six continents with more than 14 million positive cases and $>600,000$ mortalities the novel coronavirus has seized our daily lives with psychological rest and mental distress [1, 2]. COVID-19 first originated from Wuhan (Province of Hubei), the mainland of China at the end of 2019, although in the swipe of two months this virus has become an integral and alarming part of daily conversations, debates and social media updates. Two-third of the globe was under lockdown due to the arbitrary and uncertainty of infectious disease. The clinical presentation, transmissibility and the epidemiological pattern has led a call for public health emergency of international concern [3-5]. Even after stringent public health measures, the COVID19 contagion has resulted to cause psychosomatic fear, anxiety, stigma, prejudice, and marginalization towards the disease with long term worldwide challenge and detrimental effect on the well-being [6, 7]

As India is under escalation of COVID-19 cases, government, public health authorities and policymakers are guiding universal safety measures for dissemination of COVID-19 to safeguard the welfare of the general public. In accordance to a study which demonstrated the services and strategies deployed by China for the general public to minimize outbreak-related stress by the assessment of social media information reliability, intensifying social support, maintaining feasible adherence to safety measures and provision of psychosocial services [8]. However, no studies have reported the impact of the COVID-19 pandemic on mental health and quality of life combinely on Indian population. Hence, we report this novel study to evaluate the temporal psychosomatic impact on mental health as a potential risk and protective factor to provide evident information and interventions on psychological health in the Indian population.

\section{MATERIALS AND METHODS}

This Cross-sectional online survey was performed via snowball sampling technique from April 28th, 2020 to May 08th, 2020 in
India. The survey was performed amid lockdown when India has reported more than thirty thousand cases corresponding to the maximum vulnerability since the outbreak of a pandemic [9]. The questionnaire was sent by the study investigator using Emails and social media platform such as WhatsApp, Telegram, Facebook and LinkedIn to the participants. The cover page of the questionnaire includes a consent form, with a declaration of confidentiality and anonymity. The online survey included Socio-demographic data and clinical variables. Inclusion criteria include Indian citizens with more than $16 \mathrm{y}$ of age, able to read English or Hindi and have access to the internet. Whereas exclusion criteria include foreign citizen, less than $16 \mathrm{y}$ of age, unable to read English or Hindi and don't have access to internet.

\section{Ethical approval}

The purpose of the survey was explained to potential participants, who were requested to provide consent of voluntary willingness prior to their participation. All procedures performed in this study involving human participants were in adherence to the ethics of the 1964 Helsinki declaration and its later amendments or comparable ethical standards. This study was conducted and reported according to the Checklist for Reporting Results of Internet E-Surveys (CHERRIES) guidelines.

\section{Measures}

\section{Demographic characteristics}

Demographic covariates include sex (male or female), Age in years (16-25, 26-35, 36-45, 46-55, 256), Marital status (Married, Single), Education ( $\leq$ Senior Secondary, Pursuing Graduation, Graduate and $\geq$ Postgraduate), Occupation (Student, Unemployed, House-wife, Selfemployed, Unskilled, Employed), Geographical area (Urban or Rural), Area of Working (Work from home, Work from the office, Frontline worker), Living with family (Yes or No). 


\section{Depression, anxiety and stress scale (DASS-21)}

The mental health status of respondents was assessed using three self-report scales DASS-21 (Depression, Anxiety, and Stress), Psychometric scale based on a dimensional comparison of general distress in context to characteristics [10]. The questionnaire consists of 21 questions, 7 items per scale. Scores ranged from 0 (did not apply to them at all) to 3 (apply to them very much). The total depression cut-off score above 9 was classified from mild depression (10-12), moderate depression (13-20), severe depression (21-27), and extremely severe depression (28-42). In anxiety, mild Subscale cut-off scores above 7 were classified from mild anxiety (7-9), moderate anxiety (10-14), severe anxiety (15-19), and extremely severe anxiety (20-42). Stress subscale cut-off score above 10 mild stress (11-18), moderate stress (19-26), severe stress (27-34), and extremely severe stress (35-42) [11]. In our study, the Cronbach's alpha coefficient of DASS was 0.799 .

\section{Insomnia severity index (ISI-7)}

Insomnia was screened via ISI (Insomnia Severity Index) consisting of 7 items-classified under no significant insomnia, sub-threshold insomnia, moderate and severe insomnia. Response options ranged from 0 (No problem) to 4 (very severe problem) [12]. The Cronbach's alpha coefficient of the ISI scale was 0.841 and this scale presented as good internal consistency.

\section{Patient health questionnaire [PHQ-15]}

PHQ-15 (Level-2) assessed the domain of somatic symptoms from score $0-30$, each item asked for somatic symptoms during the past 7 d [13]. Each item of PHQ-15 rates from 0 (not bothered at all) to 3 (bothered at all), with higher scores indicating the severity of symptoms. Cronbach's alpha coefficient was 0.920 .

\section{Quality of life [QoL-5]}

QoL5 is a global and valid short quality of life questionnaire used for assessing practical and relevant outcome related QoL. On the numerical scoring from 1(very high) to 5(very low). Questions comprised based on physical, mental health and relationship with family and friends [14]. The construct and validity of the questionnaire presented as good and Cronbach's coefficient was 0.648.

\section{Social media exposure and mental health}

Social media exposure assessed through Source of information, how often respondents spend time exposed to news or information (less, sometimes and frequently) concerning mental distress and satisfaction regarding the availability of information.

\section{Statistical analysis}

The Data was analysed by SPSS version 22.0 (SPSS Inc., Chicago, IL USA). Mean (M) and Standard Deviation (SD) were used to describe demographic data. The percentage of responses was calculated according to the number of respondents per response to the number of total responses of a question and One-way ANOVA to assess association demographic characteristics. Multivariate logistic regression was performed to calculate the association of all variables to explore the risk dimension such as insomnia, somatic symptoms, depression, anxiety, and stress. A value of $p<0.05$ was considered significant for the entire hypothesis.

\section{RESULTS}

In the nationwide survey, we retrieved 2542 questionnaire in which 297 denied giving consent and excluded. Remaining 2245 questionnaire response was acceptable with a response rate of 88.31. The detailed demographic characteristics were demonstrated in (table 1).

Table 1: Socio-demographic variable by psychological impact $(\mathrm{N}=\mathbf{2 2 4 5})$

\begin{tabular}{|c|c|c|c|c|c|c|c|c|c|c|c|}
\hline \multirow{3}{*}{$\begin{array}{l}\text { Socio- } \\
\text { demographic } \\
\text { variable }\end{array}$} & \multirow[t]{3}{*}{$\mathrm{N}^{\ddagger}(\%)$} & \multicolumn{6}{|l|}{ Dass 21} & \multicolumn{2}{|l|}{ ISI } & \multicolumn{2}{|l|}{ PHQ 15} \\
\hline & & \multicolumn{2}{|l|}{ Depression } & \multicolumn{2}{|l|}{ Anxiety } & \multicolumn{2}{|l|}{ Stress } & \multirow[t]{2}{*}{$\mathrm{M} \pm \mathrm{SD}$} & \multirow[t]{2}{*}{$\mathbf{p}^{+}$} & \multirow[t]{2}{*}{$\mathrm{M} \pm$ SD } & \multirow[t]{2}{*}{$p^{*}$} \\
\hline & & $\mathrm{M} \pm$ SD & $\mathrm{p}^{+}$ & $\mathrm{M} \pm \mathrm{SD}$ & $\mathrm{p}^{+}$ & $\mathrm{M} \pm \mathrm{SD}$ & $\mathrm{p}^{4}$ & & & & \\
\hline \multicolumn{12}{|l|}{ Sex } \\
\hline Female & 1085(48.3) & $12.772 \pm 8.919$ & 0.83 & $10.496 \pm 5.492$ & $<0.0$ & $15.666 \pm 7.857$ & $<0.0$ & $11.217 \pm 6.172$ & $<0$ & $10.773 \pm 5.625$ & \multirow[t]{2}{*}{0.294} \\
\hline Male & $1160(51.7)$ & $12.845 \pm 6.040$ & 7 & $12.953 \pm 6.055$ & 01 & $17.140 \pm 5.181$ & 61 & $12.755 \pm 6.063$ & 001 & $10.553 \pm 11.60$ & \\
\hline \multicolumn{12}{|c|}{$12.153 \pm 0.005$} \\
\hline $16-28 \mathrm{Y}$ & $866(38.6)$ & $10.485 \pm 8.792$ & $<0.0$ & $9.439 \pm 5.255$ & $<0.0$ & $13.356 \pm 7.558$ & $<0.4$ & $9.185 \pm 6.145$ & $<0$ & $9.008 \pm 5.629$ & $<0.00$ \\
\hline $29-38 \mathrm{Y}$ & $626(27.9)$ & $13.863 \pm 6.826$ & \multirow{4}{*}{01} & $11.163 \pm 6.015$ & \multirow{4}{*}{01} & $17.578 \pm 5.026$ & \multirow[t]{5}{*}{12} & $12.128 \pm 5.430$ & \multirow[t]{5}{*}{001} & $11.09 \pm 4.419$ & \\
\hline $39-48 Y$ & $479(21.3)$ & $14.572 \pm 5.647$ & & $14.894 \pm 4.948$ & & $18.656 \pm 4.311$ & & $15.332 \pm 4.845$ & & $12.455 \pm 3.906$ & \\
\hline $49-58 \mathrm{Y}$ & $186(8.3)$ & $15.247 \pm 6.150$ & & $15.430 \pm 5.848$ & & $20.183 \pm 6.980$ & & $15.129 \pm 5.833$ & & $11.77 \pm 3.862$ & \\
\hline$>58 \mathrm{Y}$ & $88(3.9)$ & $13.455 \pm 5.080$ & & $14.182 \pm 4.064$ & & $18.409 \pm 4.560$ & & $14.398 \pm 4.960$ & & $11.681 \pm 3.538$ & \\
\hline \multicolumn{9}{|l|}{ Marital status } & & & \\
\hline Married & 1194(53.2) & $11.816 \pm 7.580$ & $<0.0$ & $12.092 \pm 6.320$ & 0.00 & $16.315 \pm 6.776$ & 0.03 & $11.674 \pm 6.132$ & 0.0 & $10.501 \pm 5.122$ & 0.107 \\
\hline Single & $1051(46.8)$ & $13.939 \pm 7.394$ & 01 & $11.395 \pm 5.404$ & 5 & $16.556 \pm 6.518$ & 9 & $12.395 \pm 6.178$ & 06 & $10.539 \pm 4.755$ & \\
\hline \multicolumn{12}{|l|}{$\begin{array}{l}\text { Geographical } \\
\text { area }\end{array}$} \\
\hline Rural & $478(21.3)$ & $16.071 \pm 6.926$ & $<0.3$ & $10.611 \pm 6.930$ & $<0.1$ & $14.142 \pm 8.990$ & $<0.0$ & $11.762 \pm 7.037$ & 0.3 & $10.769 \pm 5.414$ & 0.584 \\
\hline Urban & 1767(78.7) & $11.928 \pm 7.492$ & 01 & $12.065 \pm 5.577$ & 01 & $17.046 \pm 5.708$ & 01 & $12.079 \pm 5.905$ & 18 & $10.629 \pm 4.825$ & \\
\hline \multicolumn{12}{|l|}{ Education } \\
\hline$\leq$ Senior & $255(11.4)$ & $13.898 \pm 11.561$ & \multirow{6}{*}{$\begin{array}{l}<0.0 \\
01\end{array}$} & $12.024 \pm 5.129$ & 0.06 & $17.271 \pm 6.807$ & 0.06 & $13.149 \pm 6.742$ & $<0$ & $11.33 \pm 7.292$ & $<0.00$ \\
\hline Secondary & & & & & 0 & & 7 & & 001 & & \\
\hline $\begin{array}{l}\text { Pursuing } \\
\text { graduation }\end{array}$ & $325(14.5)$ & $18.289 \pm 5.707$ & & $12.511 \pm 5.723$ & & $17.280 \pm 4.900$ & & $15.443 \pm 4.104$ & & $11.88 \pm 4.526$ & \\
\hline$\geq$ Graduate/Po & $1665(74.2)$ & $11.574 \pm 6.549$ & & $11.581 \pm 6.056$ & & $16.132 \pm 6.897$ & & $11.168 \pm 6.148$ & & $10.32 \pm 4.532$ & \\
\hline $\begin{array}{l}\text { st-graduate } \\
\text { and above }\end{array}$ & & & & & & & & & & & \\
\hline Occupation & & & & & & & & & & & \\
\hline Housewife & $310(13.8)$ & $15.090 \pm 10.420$ & 0.02 & $13.077 \pm 5.635$ & 0.00 & $18.085 \pm 7.144$ & 0.09 & $13.326 \pm 6.523$ & $<0$ & $11.529 \pm 6.354$ & 0.168 \\
\hline Student and & $479(21.3)$ & $11.211 \pm 9.550$ & 3 & $11.106 \pm 4.329$ & 4 & $16.225 \pm 6.859$ & 7 & $10.710 \pm 5.397$ & 001 & $10.135 \pm 5.790$ & \\
\hline Unemployed & & & & & & & & & & & \\
\hline Self employed & $202(9.0)$ & $14.495 \pm 8.805$ & & $13.426 \pm 6.621$ & & $19.970 \pm 7.457$ & & $14.079 \pm 6.647$ & & $10.985 \pm 6.047$ & \\
\hline Employed & $1254(55.9)$ & $12.585 \pm 5.075$ & & $11.426 \pm 6.289$ & & $15.531 \pm 6.022$ & & $11.851 \pm 6.127$ & & $10.952 \pm 3.879$ & \\
\hline $\begin{array}{l}\text { Area of } \\
\text { working }\end{array}$ & & & & & & & & & & & 0.979 \\
\hline Work from & $944(42.0)$ & $13.297 \pm 5.173$ & 0.06 & $13.042 \pm 5.825$ & 0.01 & $16.691 \pm 5.091$ & 0.10 & $13.093 \pm 5.551$ & 0.0 & $10.89 \pm 3.528$ & \\
\hline home & & & & & 6 & & 2 & & 17 & & \\
\hline $\begin{array}{l}\text { Work from } \\
\text { office }\end{array}$ & $318(14.2)$ & $10.509 \pm 4.130$ & & $6.610 \pm 4.952$ & & $12.201 \pm 7.207$ & & $8.220 \pm 6.263$ & & $9.70 \pm 4.640$ & \\
\hline $\begin{array}{l}\text { Front line } \\
\text { worker }\end{array}$ & $124(5.5)$ & $12.774 \pm 8.979$ & & $16.419 \pm 6.573$ & & $22.016 \pm 8.086$ & & $14.395 \pm 7.544$ & & $10.48 \pm 5.843$ & \\
\hline $\begin{array}{l}\text { Not working } \\
\text { do you live }\end{array}$ & $859(38.3)$ & $13.132 \pm 10.007$ & & $11.600 \pm 4.924$ & & $16.896 \pm 6.870$ & & $11.882 \pm 5.948$ & & $10.79 \pm 6.101$ & \\
\hline with family? & & & & & & & & & & & \\
\hline No & $726(32.3)$ & $13.700 \pm 7.437$ & $<0.0$ & $13.132 \pm 6.006$ & 0.02 & $17.821 \pm 5.254$ & 0.02 & $13.405 \pm 5.634$ & $<0$ & $11.649 \pm 4.698$ & $<0.00$ \\
\hline Yes & $1519(67.7)$ & $12.384 \pm 7.593$ & 01 & $11.113 \pm 5.764$ & 1 & $15.762 \pm 7.094$ & 1 & $11.346 \pm 6.294$ & 001 & $10.188 \pm 5.007$ & 1 \\
\hline
\end{tabular}

$\ddagger \mathrm{N}=$ total number of population; $\mathrm{p}<0.05$ statistically significant 


\section{The socio-demographic and psychological impact}

The mean age of respondents was $32.4 \pm 11.4$ Larger proportion of male $(55.4 \%)$, age $18-28$ in years (38.6\%), married (53.2\%), $74.2 \%$ with the education level of $\geq$ bachelor's degree, belonging from the urban background (78.7\%), Self-employed/employed (55.9\%), Working from home (42\%) and residing with family (67.7\%) (table 1).

Mental health impact of the COVID-19 outbreak was measured by DASS-21, reporting a mean score of 21.94 (SD-7.85). For depression subscale, 317(14.12\%), 259(11.54\%), 142(6.32\%) and 63(2.81\%) are considerate under mild, moderate, severe and extremely severe depression respectively. For anxiety subscale, 393(17.46\%), $227(10.11 \%), 206(9.17 \%)$ and $101(4.50 \%)$ were considered to suffer from mild, moderate, severe and extremely severe anxiety whereas for stress scale, 339(15.10\%), 242(10.77\%), 160(7.12\%) and $83(3.70 \%)$ were considered to have mild, moderate, stress and extremely stressed. Insomnia severity index revealed a mean score of 12.01(SD=7.8). In all respondents, 592(24.85\%) had an absence of insomnia in contrast to $733(20.26 \%), 893(39.77 \%)$, and $27(1.20 \%)$ had sub threshold, moderate, severe insomnia consecutively. The multivariate logistic regression analysis (table 2) demonstrated that being a women was significantly associated with lower scores of anxiety OR-0.401[0.30, 0.52] and insomnia OR-0.751[0.68-0.826] whereas, younger age had association with lower scores of depression (OR-0.636[0.41,0.96]), anxiety (OR-0.419[0.22, 0.79]), stress (OR-0.202[0.11,0.36]), insomnia (OR-0.336[0.25-0.447]), and somatic symptoms (OR-0.168[0.08, 0.33]). In marital status, married individual showed significant association with lower level of depression (OR-0.567[0.48, 0.66]), stress (OR-0.807 [0.65,0.98]), and insomnia (OR-0.875[0.79, 0.96]) in contrast anxiety scores (OR$1.805[1.40,2.32])$ were high. Education status of pursuing graduation was associated with higher depression (OR-1.142[0.78, 1.32]), stress (OR-0.734[0.54, 099]), insomnia (OR-2.429[2.07, $2.84])$, and somatic symptoms (OR-2.597[1.80, 3.73]). In occupation, self-employed is significantly associated with higher score of stress (OR-1.998[1.38, 2.87]), and insomnia (OR-1.543[1.29,1.84]).

Table 2: Association of socio-demographic variable by psychological impact

\begin{tabular}{|c|c|c|c|c|c|}
\hline Scales & DASS 21 & & & ISI & PHQ 15 \\
\hline \multirow[t]{2}{*}{ Socio-demographic variable } & Depression & Anxiety & Stress & OR (95\%CI) & OR (95\%CI) \\
\hline & OR (95\%CI) & OR (95\%CI) & OR (95\%CI) & & \\
\hline \multicolumn{6}{|l|}{ SEX } \\
\hline Female & $1.174(0.998$ to 1.380$) *$ & 0.401 (0.309 to 0.520$)^{* *}$ & 0.824 (0.671 to 1.012$)$ & 0.751 (0.683 to 0.826$)^{* * *}$ & $1.144(0.890$ to 1.470$)$ \\
\hline Male & Reference & Reference & Reference & Reference & Reference \\
\hline \multicolumn{6}{|l|}{ AGE } \\
\hline $16-28 \mathrm{Y}$ & $0.636(0.418 \text { to } 0.968)^{*}$ & $0.419(0.220 \text { to } 0.798)^{* * * *}$ & $0.202(0.113$ to 0.360$) * * *$ & $0.336(0.253 \text { to } 0.447)^{* * * *}$ & $0.168(0.084 \text { to } 0.333)^{* * *}$ \\
\hline $29-38 \mathrm{Y}$ & $1.158(0.764$ to 1.756$)$ & $0.213(0.112 \text { to } 0.405)^{* * *}$ & $1.284(0.721$ to 2.286$)$ & $0.609(0.457$ to 0.812$) * *$ & $0.682(0.340$ to 1.368$)$ \\
\hline $39-48 \mathrm{Y}$ & 1.303 (0.855 to 1.985$)$ & $1.384(0.732$ to 2.619$)$ & 0.914 (0.508 to 1.642$)$ & 1.260 (0.937 to 1.696$)$ & $1.643(0.809$ to 3.336$)$ \\
\hline $49-58 \mathrm{Y}$ & 1.489 (0.933 to 2.378 ) & $1.417(0.698 \text { to } 2.877)^{* * * *}$ & $1.367(0.710$ to 2.362$)$ & $1.199(0.860$ to 1.671$)$ & 1.065 (0.483 to 2.348 ) \\
\hline$>58 \mathrm{Y}$ & Reference & Reference & Reference & Reference & Reference \\
\hline \multicolumn{6}{|l|}{ MARITAL STATUS } \\
\hline Married & $0.567(0.482 \text { to } 0.668)^{* * *}$ & $1.805(1.400 \text { to } 2.328)^{* * *}$ & 0.807 (0.659 to 0.988$)^{* *}$ & $0.875(0.796$ to 0.962$)$ & $0.813(0.633$ to 1.046$)$ \\
\hline Single & Reference & Reference & Reference & Reference & Reference \\
\hline \multicolumn{6}{|l|}{ GEOGRAPHICAL AREA } \\
\hline Rural & $1.297(0.801$ to 1.903$)$ & $0.899(0.647$ to 1.248$)$ & $0.281(0.215 \text { to } 0.369)^{* * *}$ & 0.943 (0.841 to 1.058 ) & $1.089(0.802 \text { to } 1.479)^{* *}$ \\
\hline $\begin{array}{l}\text { Urban } \\
\text { EDUCATION }\end{array}$ & Reference & Reference & Reference & Reference & Reference \\
\hline$\leq$ Senior Secondary & $1.026(0.612 \text { to } 1.505)^{* * *}$ & $1.342(0.909$ to 1.982$)$ & $0.693(0.502 \text { to } 0.857)^{*}$ & $1.466(1.254 \text { to } 1.715)^{* * *}$ & $1.870(1.253 \text { to } 2.791)^{* *}$ \\
\hline Pursuing graduation & $1.142(0.782 \text { to } 1.325)^{* * *}$ & $1.169(0.815$ to 1.675$)$ & $0.734(0.540$ to 0.999$) *$ & $2.429(2.070$ to 2.849$) * * *$ & $2.597(1.808 \text { to } 3.731)^{* * *}$ \\
\hline $\begin{array}{l}\geq \text { Graduate/Post-graduate and } \\
\text { above }\end{array}$ & Reference & Reference & Reference & Reference & Reference \\
\hline \multicolumn{6}{|l|}{ OCCUPATION } \\
\hline Housewife & 1.685 (1.330 to 2.134$)^{* * *}$ & 1.649 (1.154 to 2.357$)^{* * *}$ & $1.053(0.776$ to 1.429$)$ & $1.325(1.145 \text { to } 1.533)^{* * *}$ & $1.768(1.214 \text { to } 2.574)^{* * *}$ \\
\hline Student and Unemployed & $0.712(0.578$ to 0.879$) *$ & $1.053(0.759$ to 1.462$)$ & $0.877(0.679$ to 1.132$)$ & $0.809(0.718 \text { to } 0.913)^{* *}$ & $0.753(0.546$ to 1.039$)$ \\
\hline Self employed & $1.340(1.017$ to 1.766$)$ & $1.307(0.855$ to 1.998$)$ & $1.998(1.387 \text { to } 2.876)^{* * *}$ & $1.543(1.290 \text { to } 1.845)^{* * * *}$ & 1.272 (0.811 to 1.995$)$ \\
\hline Employed & Reference & Reference & Reference & Reference & Reference \\
\hline \multicolumn{6}{|l|}{ AREA OF WORKING } \\
\hline Work from home & 0.955 (0.802 to 1.138$)$ & 1.757 (1.320 to 2.339 ) & 1.108 (0.881 to 1.393 ) & $1.265(1.135$ to 1.410$) * * *$ & $1.059(0.801$ to 1.401$)$ \\
\hline Work from office & $\left(0.657(0.490 \text { to } 0.0881)^{* *}\right.$ & $0.025(0.013 \text { to } 0.046)^{* * *}$ & 1.520 (1.098 to 2.103$)^{* *}$ & $0.487(0.465 \text { to } 0.571)^{* * *}$ & $0.507(0.341 \text { to } 0.754)^{* *}$ \\
\hline Essential provider & $0.711(0.502$ to 1.008$)$ & $1.230(0.796 \text { to } 1.537)^{* * *}$ & $1.828(0.765 \text { to } 2.555)^{* * * *}$ & 1.659 (1.315 to 2.093$)^{* * *}$ & 0.828 (0.467 to 1.468$)$ \\
\hline \multirow{2}{*}{\multicolumn{6}{|c|}{ DO YOU LIVE WITH FAMILY? }} \\
\hline & & & & & \\
\hline No & $2.011(1.080-3.362)^{* * *}$ & $1.369(1.050-1.787)^{* *}$ & $1.369(1.050-1.787)$ ** & $2.670(1.206-3.841)^{* * * *}$ & $2.823(2.142-3.720)^{* * *}$ \\
\hline Yes & Reference & Reference & Reference & Reference & Reference \\
\hline
\end{tabular}

${ }^{*} \mathrm{p}<0.05 ;{ }^{* *} \mathrm{p}<0.01 ;{ }^{* * *} \mathrm{p}<0.001$; Reference- odd ratio is in reference to other subsequent variable (multinomial logistic regression)

Although other variables were high in housewife-depression (OR1.685[1.33,2.13]), anxiety (OR-1.649[1.15, 2.35]) and somatic symptom (OR-1.768[1.21, 2.57]). Working as an essential provider was significantly associated with higher score of anxiety (OR$1.230[0.79,1.53])$, stress $(1.828[0.76,2.55])$, and insomnia $(1.659[1.31,2.092])$. Not living with family was a significant predictor of depression (OR-2.011[1.08, 3.36]), anxiety $(2.10[1.65$, $3.64])$, stress $(1.369[1.05,1.78])$, insomnia (OR-2.670[1.20, 3.84]), and somatic symptom (OR-2.823[2.14, 3.72]).

\section{Quality of life and psychological impact}

Following the onset of the pandemic, approximately half of the respondents (47.9\%) reported good physical health. Additionally, $82.2 \%$ and $71.4 \%$ mentioned that they had a good relationship with their partner and friends respectively. A total of $85.8 \%$ of participants reported they feel good about themselves. On the other hand, there was an association between moderate physical health to higher odds of anxiety (OR-1.05, 95\%CI-0.993-1.742) and lower stress (OR-0.890 95\%CI-0.704-1.127) whereas poor feeling about themselves to higher depression scores (OR-1.59,95\%CI-1.12-2.280) and stress scores (OR-1.73,95\%CI-1.09-2.757) (table 3).

\section{Comparison of SME and psychological impact}

Social media exposure was "frequent" for almost half of the respondents $(47.3 \%)$, the internet was the main source of disseminating information (38.6\%) and about $41.2 \%$ were dissatisfied with the amount of information available regarding COVID-19. As shown in table 4, Multivariate analysis found that persistent exposure to media was significantly associated with higher DASS anxiety (OR-1.846, $95 \%$ CI-1.246 to 2.734) and stress scores (OR-1.073 (95 \% CI-7.911 to 1.456). The source of dissemination of health information about COVID-19 was also associated with high scores DASS anxiety (OR-2.252 (95\%CI-1.4273.554 ) 1 and stress (OR-1.908(95\% CI-1.355 to 2.688).

\section{DISCUSSION}

To our knowledge, our study is among the first to analyze the impression of COVID-19 pandemic on mental health and quality of life. $20.67 \%$ of respondents had moderate to severe depressive symptoms, $23.7 \%$ of respondents had moderate to severe anxiety symptoms and $21.5 \%$ had moderate to severe stress symptoms on DASS subscales. The prevalence of stress was higher than depression 
and anxiety in DASS subscales. This study found that compared to men, women had significantly higher depressive and somatic levels which is consistent with previous research studies $[15,16]$. Age group (49-58 y) was associated with increased anxiety scores. The elderly group is at higher risk under COVID-19 due to feeble immune system, deliberating physical activity, compromised psychological capability and co-morbid Conditions. These factors contribute to inculcating psychological effects on seniors [17].

Concerning the geographical area, rural population had increased somatic symptoms because spread in such areas is heightened due to multi-factorial reasons, including deficient of awareness, inadequate level of nutrition, sparse public health centres and most importantly ill-equipped causing prolonged stress regulating psychoneuroimmunological (PNI) releasing proinflammatory cytokines $[18,19]$.

The general public with a low level of education had a relatively higher relation to depressive scales because of a lower understanding of situations and issues. The government might mobilize resources or Social workers which can play an important role in providing sustainable awareness on physical and mental impact in simple language (diagrammatic or audio format) which can address diverse Indian population [20].

Individuals not only have to deal with the consequences of infection but also with issues concerning finance and security affecting mental health and their relationship. Housewives are related to high scores of depression, anxiety, somatic symptoms and Insomnia. LIVES is a psychosocial approach that has been developed by the World Health Organization (WHO) for women to address the prompt needs of any person who is exposed to domestic/intimate partner violence, where "L" stands for Listen means Listen to the person closely, with empathy, and without judging, "I" stands for Inquire (needs and concerns) means Inquire about emotional, physical, social and practical concerns, "V" stands for Validate means to assure and convey you believe the person, "E" stands for Enhance safety means to discuss a plan to protect the person from further harm if violence occurs again and "S" stands for Support means by providing access to information, services and social support [21].

Table 3: Association between QOL 5 and DASS subscale

\begin{tabular}{|c|c|c|c|c|c|c|c|}
\hline \multirow[t]{3}{*}{ Scales } & \multirow{3}{*}{$\mathrm{N}^{\ddagger}(\%)$} & \multicolumn{6}{|l|}{ DASS } \\
\hline & & \multicolumn{2}{|l|}{ Depression } & \multicolumn{2}{|l|}{ Anxiety } & \multicolumn{2}{|l|}{ Stress } \\
\hline & & OR $(95 \% \mathrm{CI})$ & $\mathbf{P}^{+}$ & Or $(95 \% \mathrm{CI})$ & $\mathbf{P}^{*}$ & OR $(95 \% \mathrm{CI})$ & $\mathbf{P}^{+}$ \\
\hline $\begin{array}{l}\text { How do you consider your physical health } \\
\text { at the moment? }\end{array}$ & $499(22.2)$ & 1.207 (0.986 to 1.478$)$ & 0.068 & 1.155 (0.837 to 1.594$)$ & 0.380 & $1.250(0.968$ to 1.614$)$ & 0.880 \\
\hline Poor & $671(29.9)$ & 1.185 (0.837 to 1.594$)$ & 0.072 & $1.051(0.933$ to 1.742$)$ & $<0.001$ & 0.890 (0.704 to 1.127$)$ & 0.034 \\
\hline $\begin{array}{l}\text { Moderate } \\
\text { Good }\end{array}$ & $1075(47.9)$ & Reference & Reference & Reference & Reference & Reference & Reference \\
\hline $\begin{array}{l}\text { How do you consider your mental health } \\
\text { at the moment? }\end{array}$ & $256(11.4)$ & 0.937 (0.728 to 1.205$)$ & 0.611 & $0.911(0.614$ to 1.354$)$ & 0.646 & $1.162(0.847$ to 1.595$)$ & 0.351 \\
\hline Poor & $385(17.1)$ & 0.911 ( 0.614 to 1.354$)$ & 0.621 & 0.909 (0.759 to 1.477$)$ & 0.736 & $0.971(0.743$ to 1.269$)$ & 0.828 \\
\hline $\begin{array}{l}\text { Moderate } \\
\text { Good }\end{array}$ & $1604(71.4)$ & Reference & Reference & Reference & Reference & Reference & Reference \\
\hline $\begin{array}{l}\text { How is your relationship with your } \\
\text { partner at the moment? }\end{array}$ & $165(7.3)$ & $0.868(0.638$ to 1.180$)$ & 0.366 & $1.209(0.624$ to 1.632$)$ & 0.971 & $0.992(1.677$ to 1.455$)$ & 0.968 \\
\hline Poor & $234(10.4)$ & $0.773(0.651$ to 1.262$)$ & 0.651 & $1.179(0.788$ to 1.763$)$ & 0.423 & 0.906 ( 0.692 to 1.333$)$ & 0.810 \\
\hline $\begin{array}{l}\text { Moderate } \\
\text { Good }\end{array}$ & $1846(82.2)$ & Reference & Reference & Reference & Reference & Reference & Reference \\
\hline $\begin{array}{l}\text { How is your relationship with your friends } \\
\text { at the moment? }\end{array}$ & $166(7.4)$ & $1.524(1.124$ to 2.064$)$ & 0.066 & 1.727 (1.448 to 2.182 ) & 0.199 & $0.958(0.618$ to 1.327$)$ & 0.611 \\
\hline Poor & $341(15.2)$ & $1.227(0.949$ to 1.587$)$ & 0.118 & 0.905 (0.614 to 1.355$)$ & 0.627 & 0.921 ( 0.667 to 1.273 ) & 0.620 \\
\hline $\begin{array}{l}\text { Moderate } \\
\text { Good }\end{array}$ & $1838(77.4)$ & Reference & Reference & Reference & Reference & Reference & Reference \\
\hline $\begin{array}{l}\text { How do you feel about yourself at the } \\
\text { moment? }\end{array}$ & $110(4.9)$ & $1.598(1.120$ to 2.280$)$ & 0.010 & $0.869(0.498$ to 1.515$)$ & 0.619 & 1.733 (1.090 to 2.757$)$ & 0.020 \\
\hline Poor & $208(9.3)$ & $0.983(0.749$ to 1.591$)$ & 0.903 & $0.812(0.797$ to 1.844$)$ & 0.368 & $1.127(0.798$ to 1.591$)$ & 0.497 \\
\hline $\begin{array}{l}\text { Moderate } \\
\text { Good }\end{array}$ & $1927(85.8)$ & Reference & Reference & Reference & Reference & Reference & Reference \\
\hline
\end{tabular}

${ }^{\ddagger} \mathrm{N}=$ total number of population; ${ }^{\natural} \mathrm{p}<0.05$ statistically significant; Reference-odd ratio is in reference to other subsequent variable (multinomial logistic regression)

Table 4: Association between social media exposure and DASS subscale

\begin{tabular}{|c|c|c|c|c|c|c|c|}
\hline \multirow[t]{3}{*}{ Scales } & \multirow[t]{3}{*}{$\mathrm{N}^{\ddagger}(\%)$} & \multicolumn{6}{|l|}{ DASS } \\
\hline & & \multicolumn{2}{|l|}{ Depression } & \multicolumn{2}{|l|}{ Anxiety } & \multicolumn{2}{|l|}{ Stress } \\
\hline & & OR $(95 \% \mathrm{CI})$ & $\mathbf{P}^{*}$ & OR $(95 \% \mathrm{CI})$ & $\mathrm{P}^{*}$ & OR $(95 \% \mathrm{CI})$ & $\mathbf{P}^{*}$ \\
\hline \multicolumn{3}{|c|}{ How many times in a day, you are } & 0.311 & $1.846(1.246$ to 2.734$)$ & 0.002 & $1.073(7.911$ to 1.456$)$ & 0.650 \\
\hline Frequently & $874(38.9)$ & 0.871 (678 to 1.119 ) & 0.281 & $1.397(0.932$ to 2.094$)$ & 0.105 & $0.597(0.673$ to 1.255$)$ & 0.919 \\
\hline Sometimes & $308(13.7)$ & Reference & Reference & Reference & Reference & Reference & Reference \\
\hline \multicolumn{8}{|c|}{ Less } \\
\hline \multicolumn{8}{|c|}{$\begin{array}{l}\text { The primary source of information } \\
\text { on COVID-19 }\end{array}$} \\
\hline Other sources & $149(6.6)$ & $1.053(0.711$ to 1.156$)$ & 0.796 & $1.213(0.636$ to 2.315$)$ & 0.557 & 1.463 (0.899 to 2.382$)$ & 0.126 \\
\hline Radio & $178(7.9)$ & 0.778 (0.533 to 1.136$)$ & 0.194 & $1.576(0.849$ to 2.924$)$ & 0.149 & $1.141(0.717$ to 1.816$)$ & 0.578 \\
\hline Television & $793(35.3)$ & $0.822(0.668$ to 1.165$)$ & 0.376 & $1.868(1.179$ to 2.960$)$ & 0.008 & $1.507(1.069$ to 2.124$)$ & 0.019 \\
\hline Internet & $867(38.6)$ & 0.767 (0.581 to 1.012$)$ & 0.061 & $2.252(1.427$ to 3.554$)$ & $<0.001$ & 1.908 (1.355 to 2.688$)$ & $<0.001$ \\
\hline \multirow{2}{*}{\multicolumn{8}{|c|}{$\begin{array}{l}\text { Satisfaction with the health } \\
\text { information available about COVID- } \\
19\end{array}$}} \\
\hline & & & & & & & \\
\hline Do not know & $65(2.9)$ & $0.855(0.480$ to 1.523$)$ & 0.595 & $0.389(0.148$ to 1.022$)$ & 0.055 & $1.029(0.522$ to 2.027$)$ & 0.934 \\
\hline Not satisfied at all & $195(8.7)$ & $1.168(0.783$ to 1.741$)$ & 0.447 & 0.934 (0.489 to 1.782$)$ & 0.835 & $0.653(0.398$ to 1.070$)$ & 0.091 \\
\hline Not very satisfied & $925(41.2)$ & $1.257(0.919$ to 1.718$)$ & 0.152 & 1.047 (0.637 to 1.723$)$ & 0.850 & $1.075(0.729$ to 1.586$)$ & 0.714 \\
\hline somewhat satisfied & $886(39.5)$ & 1.087 (0.794 to 1.488$)$ & 0.602 & $1.805(1.095$ to 2.9750$)$ & 0.021 & $0.829(0.560$ to 1.226$)$ & 0.347 \\
\hline Very satisfied & $174(7.8)$ & Reference & Reference & Reference & Reference & Reference & Reference \\
\hline
\end{tabular}

${ }^{*} \mathrm{~N}=$ total number of population; $\mathrm{p}<0.05$ statistically significant; Reference-odd ratio is in reference to other subsequent variable (multinomial logistic regression) 
Also, it was found that front line workers had heightened psychological distress might be due to high risk of pathogen exposure, insufficient understanding of the virus, insufficient prevention and control, lack of personal protective equipment which can be exemplified from Chinese study impacting the mental health of 1257 health care workers [24]. Interestingly, residing with the family acted as protective factors against the negative mental impact caused by COVID-19.

Limiting external outing due to lockdown has significant implications on quality of life especially reduced physical activity. COVID-19 had considerable consequence immune response, especially involving and injuring helper and suppressor T cells [25]. As immunity and psychological stress are related inversely, Yoga therapy aims to reduce psychological stress and strength immunity. Studies have suggested yogic practices (40-min) aims to improve overall health, enhance lung capacity and biorhythm [26].

The study highlighted social media exposure and effect implications. As our data was congruous with previous studies reporting SME was associated with higher odds of anxiety and stress [27]. The reason behind this association might be due to the global epidemic of misinformation and rumours through social media platforms which may confuse and affect mental health. So, the WHO infodemics team is working hand in hand with agencies and countries [28]. Additionally, government and health care authorities should provide evidencebased information to the general public to avoid psychological reactions as higher satisfaction with health information is directly related to lower levels of depression, anxiety, and stress.

Government of India is taking measures on the front to preserve the mental health of citizens indirectly or directly through providing all necessary information of pandemic on the government portal, various helpline numbers had been activated to assist regarding any inquiry and advisories, videos and webinars are being conducted for handing issues on mental health [29]. Possible limitations of the study were a cross-sectional design which doesn't elucidate strong evidence. Thus, longitudinal study designs are essential for future studies. Studies targeting elderly and frontline workers in the future from India will help in understanding greater mental health impact.

The self-reporting pattern and snow-ball sampling technique can't align with the assessment percepts of mental health professionals. Lastly, the possibility of some effect due to residual confounding in unmeasured characteristics.

\section{CONCLUSION}

In summary, our finding identified targeting population i.e. women especially housewives, elderly, frontline workers and respondents with low education levels are influential factors for mental health problems. Positive association poor QoL and frequent social media exposure to psychological distress. Therefore, the Government should develop imperative resources and methods to provide psychological resilience and well-being to all sections of society considering socio-demographic characteristics.

\section{ABBREVIATION}

QoL-Quality of life, ISI-Insomnia Severity Index, SME-Social media exposure,

\section{FUNDING}

Nil

\section{AUTHORS CONTRIBUTIONS}

Data collection and drafting of data was done by Dr. Preeti Raj and Dr. Pratima Singh, Dr. Supriya suman contributed in data analysis, interpretation and critical revision of the manuscript. Final approval was done by Mr. Deepak Nathiya and Dr. Balvir Singh Tomar.

\section{CONFLICT OF INTERESTS}

The author declares that they have no conflict of interest.

\section{REFERENCES}

1. Coronavirus Graphs: Worldwide Cases and Deaths; 2020. Available from: https://www.worldmeters.info/coronavirus [Last accessed on 05 Jul 2020]
2. Xiao C. A novel approach of consultation on 2019 novel coronavirus (COVID-19)-related psychological and mental problems: structured letter therapy. Psychiatry Investigation 2020;17:175-6.

3. Li Q, Guan X, Wu P, Wang X, Zhou L, Tong Y. Early transmission dynamics in wuhan, china, of novel coronavirus-infected pneumonia. New England J Med 2020;382:1199-207.

4. COVID-19: too little, too late? The Lancet 2020;395:755.

5. Day M. Covid-19: surge in cases in Italy and South Korea makes pandemic look more likely Br Med J 2020;368:m751.

6. Mak I, Chu C, Pan P, Yiu M, Chan V. Long-term psychiatric morbidities among SARS survivors. General Hospital Psychiatry 2009;31:318-26.

7. Xiang Y, Yang Y, Li W, Zhang L, Zhang Q, Cheung T. Timely mental health care for the 2019 novel coronavirus outbreak is urgently needed. Lancet Psychiatry 2020;7:228-9.

8. Rubin E, Baden L, Morrissey S, Campion E. Medical journals and the 2019-nCoV outbreak. New England J Med 2020;382:866-6.

9. India Situation Report; 2020. Available from: https://www.who.int/india/emergencies/india-situationreport [Last accessed on 05 Jul 2020]

10. Lovibond $\mathrm{P}$, Lovibond $\mathrm{S}$. The structure of negative emotional states: comparison of the depression anxiety stress scales (DASS) with the beck depression and anxiety inventories. Behaviour Res Ther 1995;33:335-43.

11. McAlonan G, Lee A, Cheung V, Cheung C, Tsang K, Sham P. Immediate and sustained psychological impact of an emerging infectious disease outbreak on health care workers. Canadian J Psychiatry 2007;52:241-7.

12. Niharika D, Niharika B, Aishwarya T, Nikitha A, Butool R, Ibrahim $\mathrm{M}$, et al. Coronavirus-a virus in learning. Int J Curr Pharm Res 2020;12:7-10.

13. Kroenke K, Spitzer R, Wiliams J. The PHQ-15: validity of a new measure for evaluating the severity of somatic symptoms. Psychosomatic Med 2002;64:258-66.

14. Lindholt JS, Ventegodt S, Henneberg EW. Development and validation of QoL 5 for clinical databases. a short, global and generic questionnaire based on an intergrated theory of the quality of life. Eur J Surg 2002;168:107-13.

15. Wang C, Pan R, Wan X. A longitudinal study on the mental health of general population during the COVID-19 epidemic in China. Brain Behavior Immunity 2020;87:40-8.

16. Rossie R, Socci V, Pacitti F, Di LG, Di MA, Siracusano A. R mental health outcomes among frontline and second-line health care workers during the coronavirus disease 2019 (COVID-19) pandemic in italy. JAMA Network Open 2020;3:e2010185.

17. Pradeep K Gau, Vinay Bhatia, Parveen Singla, Abhishek Sharma, Gagandeep Kaur, Gurpreet Singh. Unified approach to detect covid-19 in patients. JCR 2020;7:2518-23.

18. Viljoen M, Panzer A. Proinflammatory cytokines: a common denominator in depression and somatic symptoms? Canadian J Psychiatry Revue Canadienne De Psychiatrie 2005;50:128.

19. Singh S, Badaya S. Health care in rural India: A lack between need and feed. South Asian J Cancer 2014;3:143-4.

20. Wang C, Pan R, Wan X, Tan W, Xu L. Immediate psychological responses and associated factors during the initial stage of the 2019 coronavirus disease (COVID-19) epidemic among the general population in China. Int J Environ Res Public Health 2020;17:1729.

21. World Health Organisation. Health care for women subjected to intimate partner violence or sexual violence: A clinical handbook. Geneva; 2014.

22. Giorgi G, Arcangeli G, Mucci N, Cupelli V, Giorgi G. Economic stress in workplace: the impact of fear the crisis on mental health. Work 2015;51:135-42.

23. Nicola M, Alsafi Z, Sohrabi C, Kerwan A, Al-Jabir A, Iosifidis C. The socio-economic implications of the coronavirus pandemic (COVID-19): a review. Int J Surgery 2020;78:185-93.

24. Lai J, Ma S, Wang Y, Cai Z, Hu J. Factors associated with mental health outcomes among health care workers exposed to coronavirus disease 2019. JAMA Netw Open 2020;3:e203976. 
25. Qin C, Zhou L, Hu Z, Zhan S, Yang S, Tao Y. Dysregulation of immune response in patients with COVID-19 in Wuhan, China. Clin Infect Dis 2020;12:248.

26. Segerstrom S, Miller G. Psychological stress and the human immune system: a meta-analytic study of $30 \mathrm{y}$ of inquiry. Psychological Bulletin 2004;130:601-30.

27. Gao J, Zheng P, Jia Y, Chen H, Mao Y, Chen S. Mental health problems and social media exposure during COVID-19 outbreak. SSRN Electronic Journal 2020;15:e0231924.
28. WHO. Director-General's remarks at the media briefing on 2019 novel coronavirus; 2020. Available from: https://www.who.int/dg/speeches/detail/director-general-sremarks-at-the-media-briefing-on-2019novel-coronavirus. [Last accessed on $08 \mathrm{Feb} 2020]$.

29. Hiremath P, Suhas K, Manjunath M, Shettar M. COVID 19: impact of lock-down on mental health and tips to overcome. Asian J Psychiatry 2020;51:102088. 